\title{
DRIVING AND RESTRAINING FORCES OF FEMALE LATIN AMERICAN ENTREPRENEURSHIP
}

\author{
Anel Flores-Novelo* \\ https://orcid.org/0000-0003-2567-8769 \\ Ana Laura Bojórquez Carrillo** \\ https://orcid.org/0000-0003-0830-2508 \\ Gabriela Carla Cuadrado Barreto*** \\ https://orcid.org/0000-0002-8562-7843
}

RECIBIDO: Mayo 2021 / ACEPTADO: Julio 2021 / PUBLICADO: Septiembre 2021

\begin{abstract}
Como citar: Flores-Novelo, Anel; Bojórquez Carrillo, Ana; Cuadrado Barreto, Gabriela. (2021). Driving and restraining forces of female latin american entrepreneurship. Telos: revista de Estudios Interdisciplinarios en Ciencias Sociales, 23 (3), Venezuela. (Pp. 668-691).

DOI: www.doi.org/10.36390/telos233.11
\end{abstract}

\begin{abstract}
Women in Latin America present unique challenges and opportunities due to the family responsibilities they assume because of their gender role. The article focuses on examining the driving forces for Latin American entrepreneurship as empowerment and family support, and the restraining forces as their exclusion from males spheres, labor discrimination, lack of support, and families responsibilities from an intersectionality approach. The study includes the implications of how the entrepreneurial phenomenon develops in the context of women in Latin American. Studies of this type in this context being scarce. Likewise, an analysis of entrepreneurial femininity is carried out to identify the most appropriate Latin context. Equally, an analysis model is proposed that integrates these driving and restrictive forces. The methodology is qualitative, cross-sectional, integrates the case study, semi-structured in-depth interviews, and discourse interpretation. The conclusion presents the women barriers face in startup businesses and how their family responsibilities limit them, being the key support for their development, especially in Latin American when they face a macho atmosphere and a social representation associated with femininity (seems to be contrary to entrepreneurial spirit), the main role of women

\footnotetext{
* Doctora en Ciencias de la Administración, Profesor Titular de Tiempo completo de la Universidad Autónoma de Yucatán, México. Correo electrónico anel.flores@correo.uady.mx

** Doctora en Estudios del Desarrollo, Problemas y Perspectivas Latinoamericanas, Investigadora Titular de Tiempo Completo de la Universidad Autónoma de Yucatán, México. Correo electrónico: anabc@correo.uady.mx

*** Doctora en Ciencias de la Administración, Docente Investigadora Titular de Tiempo Completo Universidad Politécnica Estatal del Carchi, Ecuador. Correo electrónico: gabriela.cuadrado@upec.edu.ec
} 
in the home, without economic support, with financial responsibility for taking care of their families, is shown as a cause for businesses not to grow.

Keywords: entrepreneurship; Latin America; women; family support; Family-Work Enrichment; empowerment; intersectionality.

\section{Fuerzas impulsoras y restrictivas del emprendimiento femenino Latinoamericano}

\section{RESUMEN}

Las mujeres en América Latina presentan desafíos y oportunidades únicos debido a las responsabilidades familiares que asumen por su rol de género. Este artículo se centra en las fuerzas impulsoras del emprendimiento latinoamericano como el empoderamiento y el apoyo familiar, y las fuerzas restrictivas como su exclusión del ámbito masculino, la discriminación laboral, la falta de apoyo y las responsabilidades familiares. El estudio incluye las implicaciones de cómo se desarrolla el fenómeno emprendedor en el contexto de las mujeres en América Latina. Los estudios de este tipo en este contexto son escasos. Asimismo, se realiza un análisis de la feminidad emprendedora para identificar la más adecuada al contexto latino. De igual forma, se propone un modelo de análisis que integra estas fuerzas impulsoras y restrictivas. Este trabajo se hizo bajo un enfoque cualitativo. Se elaboró bajo un diseño transversal, aplicando el método de caso. La recolección de datos se hizo a través de entrevistas en profundidad semiestructuradas y su análisis a través de la técnica de interpretación del discurso. La conclusión presenta las barreras que enfrentan las mujeres en sus emprendimientos y cómo sus responsabilidades familiares las limitan, siendo el soporte clave para su desarrollo, especialmente en la latinoamericana cuando enfrentan un ambiente machista y una representación social asociada a la feminidad (al parecer contrario al espíritu emprendedor), el protagonismo de la mujer en el hogar, sin apoyo económico, con la responsabilidad económica del cuidado de sus familias, se muestra como una causa para que los negocios inicien, pero no crezcan.

Palabras clave: emprendimiento; América Latina; mujeres; apoyo familiar; enriquecimiento Familia-Trabajo; empoderamiento; interseccionalidad.

\section{Introduction}

According to a study by the Economic Commission for Latin America and the Caribbean (ECLAC), part of the United Nations, in Latin America, there are profound gender biases. The main ones are: lower participation of women in employment, their concentration in economic and occupational sectors with lower productivity and lower levels of income, vertical segregation, wage gaps, sexual division of work, causes by which barriers are formed for the economic autonomy of women by assigning an overload of domestic work and unpaid care. Likewise, gender gaps in the work world are deepening with the emergence of new types of work that weaken labor relations by establishing flexible schemes that do not have the necessary regulations to guarantee labor rights (Vaca-Trigo, 2019).

The "gender gap" persists in entrepreneurship even when there are an estimated 163 million women entrepreneurs (Byrne et al., 2019). In Latin America, 51.8\% of women are 
employed in sectors classified as low productivity, and of these, $82.2 \%$ are not affiliated or contributing to a pension system. Women also represent $62 \%$ of unpaid contributing family workers. In the absence of job opportunities, A significant percentage of women find themselves in need of self-employment and create companies; however, only $3.4 \%$ of the total employment of women represents the section of female employers, compared to $5.7 \%$ of employed men within this category. Most of the women who manage to enter the business world do so by operating micro-businesses in the informal economy, women have not benefited from the opportunities of globalization and digitization, in addition to the fact that companies operated by women are less likely to export and to participate in international transactions, and to obtain credits to finance their activities. Thus, most women owners of SMEs in Latin America are $27 \%$ less likely to receive a loan from a bank to found their business than a man. Latin America is the region where a greater number of women microentrepreneurs obtain their initial capital from their husbands (17\% of women microentrepreneurs), which generates a vicious circle against their autonomy (VacaTrigo, 2019).

Even in developed countries, persist lacks of confidence in the ability of women to start and develop businesses. There are unacceptable funding gaps across OECD countries. For example, in the United States, there is a $60 \%$ chance that investors will choose a man-made business proposal. Women-led startups receive on average $23 \%$ less funding than men's. In addition, women-run businesses are less global in nature, as well as less likely to export their products and participate in international business. Only $37 \%$ of women in OECD countries believe they have the skills required to start a business compared to $51 \%$ of men. Also, women are about $56 \%$ less likely to be entrepreneurs in the formal sector and $63 \%$ more likely to be entrepreneurs in the informal sector (Gurría, 2018).

Stereotypes based on gender limit opportunities for women in the business context; Although are many stereotypic beliefs give a different threat to women leaders: "women are seen as lacking leadership qualities" (Véras, 2015, p. 110).

This kind of discrimination is analyzed in this work throw by intersectionality approach, which "reveals the inequalities that are produced by the interaction between the subordination systems of gender, sexual orientation, ethnicity, religion, origin, (dis) ability and socioeconomic situation, which constitute one to another dynamically in time and space" (La Barbera, 2016, p. 105). And whose interactions made visible in terms of power Intersectionality emerged at the end of the eighties, having its origin in the studies of anti-racist feminisms popularized by Kimberle Crenshaw (La Barbera, 2016; Lázaro \& Jubany, 2017).

The relevance of his studies was to show that the losses are contained in the practices, perceptions, and representations of people that are projected against individuals or social groups (Lázaro \& Jubany, 2017). Intersectionality has been one of the most important contributions to feminist theory and praxis in recent years (McCall cited by La Barbera, 2016). Since the postcolonial era, the subject characterized as "woman" soil has been very reduced. Although there are subsections within this problem with more discriminatory problems when compared with indigenous women, Muslims, immigrants, black women, and lesbians (Lázaro \& Jubany, 2017 ), that is, a woman could suffer accumulated discrimination for being a woman, poor, immigrant and indigenous, as a person at a disadvantage to women with a better economic situation, non immigrant and indigenous women. 
According to La Barbera (2016), intersectionality developed mainly in the Anglo-Saxon academic enviroment; the author suggests it should be explored more and have a greater diffusion outside that Anglo-Saxon territory.

Gender inequalities increase in a business environment owing to the family responsibilities of both men and women. This ethnocentrism has continued for decades, which is why the United Nations has included gender equality, in all contexts, as one of the Sustainable Development Goals (SDGs) (United Nations, 2020).

Feminine social duties limit their human development and autonomy. This work discusses the implications of these limitations in the workplace and specifically in their ventures. This problem is particularly complex in Latin America, given the importance of the family in cultural and social aspects and the preponderant role of women in it. In response, this article provides a theoretical review of the subject and highlights the importance of developing a particular perspective for Latin America, whose cultural, economic, political, and ecological differences imply unique challenges and opportunities for women.

Facing this problem, this work focuses on examining the driving forces for Latin American entrepreneurship as empowerment and family support, and the restraining forces as their exclusion from males spheres, labor discrimination, lack of support, and families responsibilities from an intersectionality approach

The theoretical framework to the discussion deals in the first instance with the male model theme for entrepreneurship, the women barriers entrepreneurs face. Follow by a discussion of the empowerment and entrepreneurship in the female context, then continue with family and the entrepreneur, and later tackles a brief review of the studies that discuss the entrepreneurial femininities, ending with a model that integrates the whole theoretical discussion. Subsequently, the methodology is presented with the development of two cases of entrepreneurs who see their limited business oportunities due to their gender status and the family support received. Finally, a discussion of cases and conclusions are presented.

\section{Male model for entrepreneurship}

Entrepreneurship is dominantly a male dominated phenomenon in most societies of the world. It has been widely argued that women do not get equal opportunities than men to enter entrepreneurship. The entrepreneur identity is often described in masculine, youthful and agentic terms that contradict internalized norms, expectations, behaviors, actions, and motivation of women entrepreneurs' multiple identities (Drencheva, 2019; Raghuvanshi et al., 2017) . In Mexico, the difference between men and women in the financial themes of self-employed or entrepreneurs is large, shown in Figure 1. In every country of OECD, women represent a lower share of employers and entrepreneurs than men. 
Figure 1. Women represent a low share of employers and entrepreneurs

a. Share of self-employed

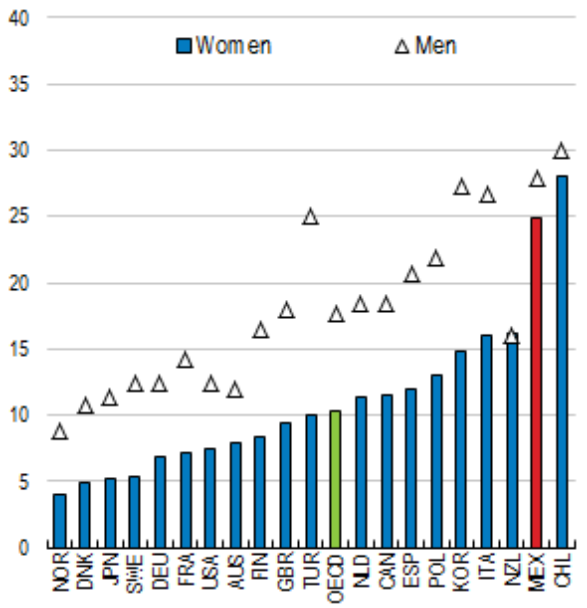

b. Share of employers

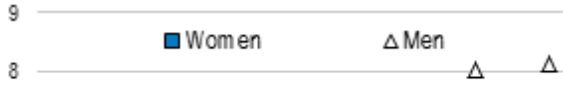

$\Delta$
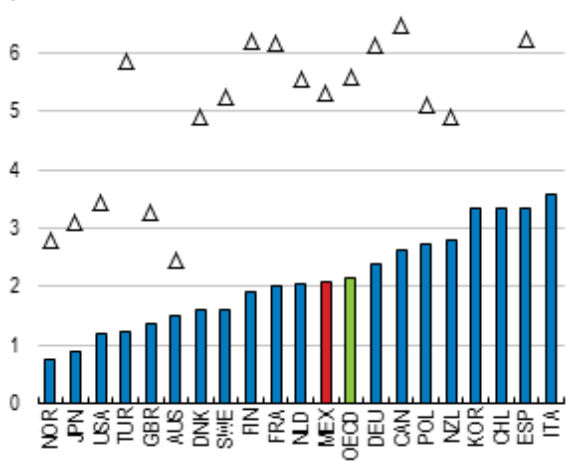

Source: Fareed et al. (2017)

In addition, women usually have less access to bank loans for their business financing than men (Figure 2).

Figure 2. Use of bank loans for business financing.

Percentage of respondents pointing to the financing source, by gender of ownership or management;

$$
\text { Jan-Apr - } 2018
$$

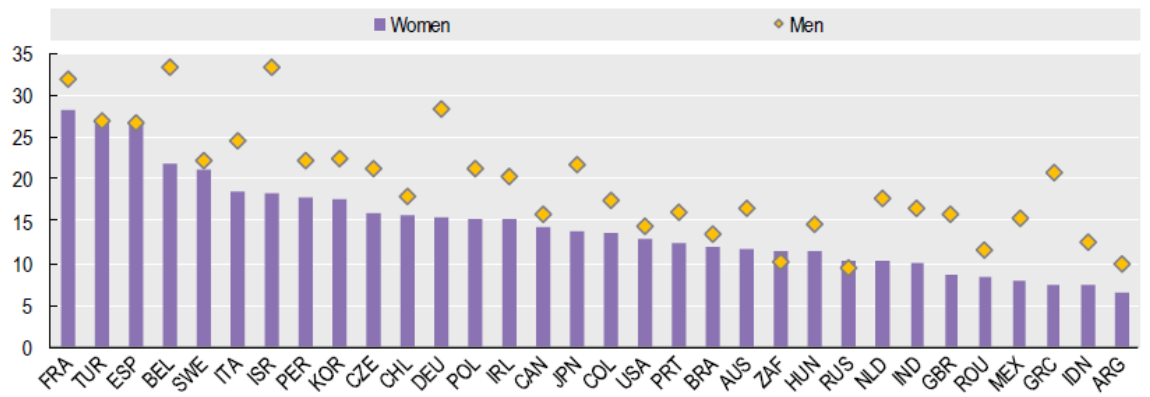

Source: OECD (2018, p. 14).

Other differences are related to the motivation to set up a business. Women's motivations are more related to pursue and interest or hobby than to make more money (OECD, 2018) (See Figure 3). This can create a different perspective of what an entrepreneur (in male connotation) "should" be. In this sense, Byrne et al., (2019) identify new entrepreneurial femininity: the fun-preneur; this is because many women entrepreneurs stress the personal pleasure and enjoyment that entrepreneurship can bring (doing "fun"), although this can come at 
a cost for these women. "In depicting women's entrepreneurship as fun-preneurship, women are positioned as secondary to men and thereby risk sustaining a male norm" (p. 3).

Figure 3. Motivations to set up a business.

Percentage of respondents pointing to the option, by gender of ownership or management;

Feb-Apr - 2018
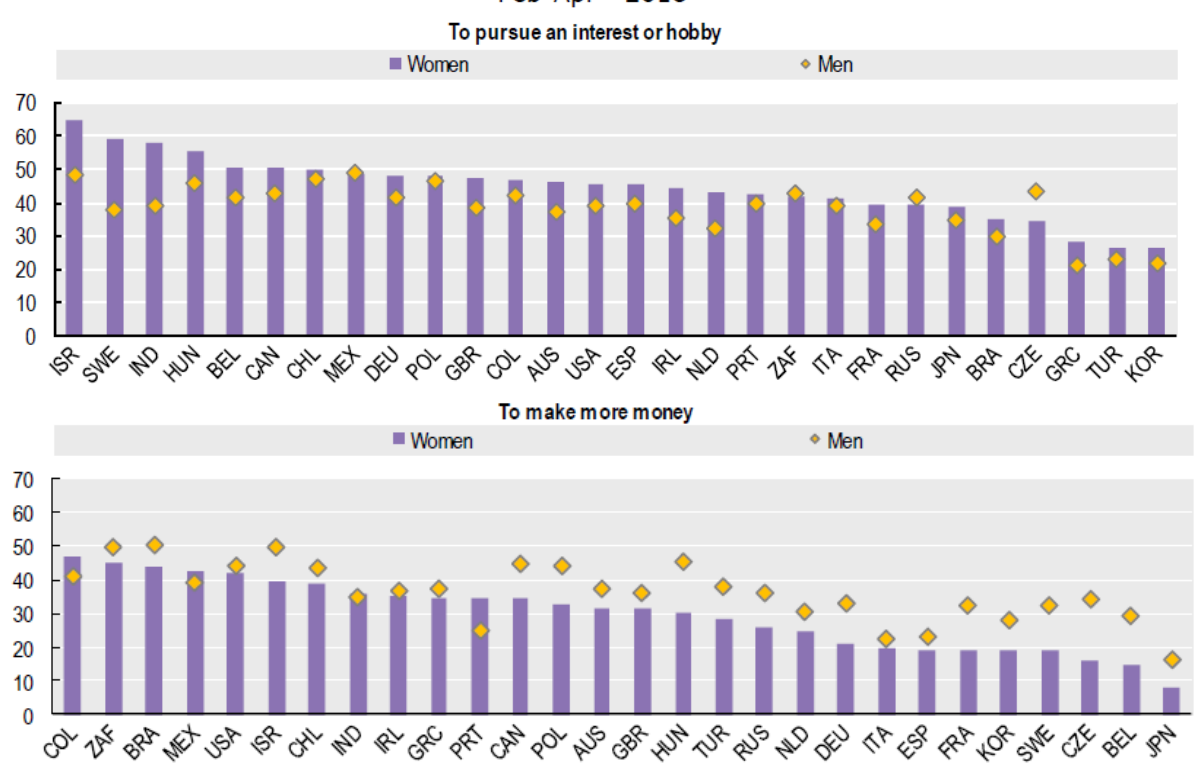

Source: OECD $(2018$, p. 14)

Although, according to the Figure 3, women's motivation to set up a business is more for the interest of hubby than to make money, authors such as Laguia et al., (2018) and Byrne et al., (2019) assure that entrepreneurship is one possible career path that alleviates problems women face in the traditional workplace, such as: difficult to complete the work hours (due to child care obligations), other work-family conflicts, barriers to their advancement based on stereotypical beliefs, negatively skewed performance evaluations when compared to men, glass ceiling, poorer chances of being promoted than their male counterparts, penalization for their success by being disliked and interpersonally derogated, the backlash against successful women or less available opportunities for mentorship and networking within organizations compared to men. Also, related to ecosystem factors, women, in general, are at a disadvantage in comparison with men.

\section{Women as Entrepreneur}

Accepting that having the body of a woman or man does not automatically assign you certain skills, desires, or leads you to perform certain activities, professions, or jobs, opens a more complex picture in society, more enriching and just; but also, that threatens the status quo of many social groups in the fields: religious, political, and economic that have used this argument and whose rejection implies the questioning of its deepest roots. 
While progress has been made to increase control over their own lives and environment, there is also a way to achieve evolution and reconfiguration of family, social, and employment relationships aimed at achieving equity conditions. Every day there are a greater number of households whose income depends on both men and women, giving rise to a different family dynamic, and therefore, it is moving towards a change in the identity of the female gender (Rodrigues et al., 2020; Gálvez, 2001; Lin et al., 2018)

One area that has captured the attention of researchers in recent times is female entrepreneurship in developing countries. Given the importance of their role in the family, women often go through difficulties finding and maintaining a job, so they have turned to open businesses that provide them with that flexibility and combine their family and professional (Henry et al., 2016; Mirchandani, 2002)

Institutions such as Grupo Banco Mundial (2018) and the Global Entrepreneurship Monitor (GEM) agree that in the last decade, women-driven business initiatives have been on the rise, positively impacting the economy. According to GEM, the gender gap (proportion of women to men taking part in entrepreneurship) narrowed by 5\% from 2015 to 2017 (Kelley et al., 2017).

Henry, Foss, \& Ahl (2016) reveal there is a large proliferation of studies comparing men and women, often trying to identify differences and supporting their findings with statistical evidence but report there is a lack of deep qualitative studies to understand the origins of these differences.

Marlow (2002) have incorporated critical assessments from the feminist perspective, around women in the business field facing an androcentric society, which causes restrictions on the construction of their economic and social capital, with those restrictions being better explaining the poor performance of their companies, than simply attributing it to characterizations of their gender.

In other words, the low financial performance, the lack of growth expectations, its concentration in non-technological sectors, and the low contribution to employment that women's ventures cost (Kelley et al., 2017) is not due to their gender status. However, to the structural constraints, they therefore face. This is known as the "female under-performance hypothesis" (Ahl, 2006).

Ogbor (2000) followed this perspective and incorporated more appropriate definitions of the word gender, such as "social practices" and "representations associated with femininity or masculinity" incorporating the analysis of the social and material implications of gender into the discussion of entrepreneurship in management.

Raghuvanshi, Agrawal, and Ghosh (2017) identify these 14 types of barriers to women's entrepreneurship, which severely inhibit entrepreneurial endeavors of women, especially in under-developed areas and male-dominated societies:

1. Less interested in entrepreneurial activities.

2. Problem in acquiring financial resources.

3. Adopt different strategic practices.

4. Slow growth.

5. Less monetary benefits.

6. High shut down rates.

7. Lack of institutional support. 
8. Spatial mobility and lack of family support.

9. Lack of marketable skills.

10. Lack of social connectivity.

11. Lack of entrepreneurial management.

12. Absence of technological know-how.

13. Lack of propensity to take a risk.

14. Lack of education, experience and, training opportunities

Of these 14 identified barriers, the authors argue that lack of education, experience and training opportunities, spatial mobility, and lack of institutional support emerged as the biggest challenges for women's entrepreneurship.

\section{Women empowerment through entrepreneurship}

Shettar (2020) confirms that "women empowerment refers to increasing the spiritual, political, social, educational, gender or economic strength of individuals and communities of women" (p. 3843). Indeed, empowerment makes women have control over their lives, including control over resources and ideology, which increases self-confidence. Empowering women is empowering the community, this will have a direct impact on the welfare of families in the communities, so women entrepreneurs play a key role in economic resilience (Asfiah et al., 2018).

In this sense, entrepreneurship can be an important tool for women's empowerment, since it could help bring gender equality and improve their economic situation since it gives them a job option under their control and can allow them to balance their female roles, especially in the family environment.

Entrepreneurship has been highlighted as a crucial way to reduce unemployment and improve the economic situation; the underlying idea is that if entrepreneurship is coupled with sustainable technological, social, and cultural advances, there are significant societal and economic benefits to be gained (Byrne et al., 2019).

According to Asfiah et al., (2018) three principal elements distinguish an entrepreneur:

- They can sense opportunities, which are often based on deep personal knowledge and experience.

- They find and pursue desired opportunities in different life situations.

- They believe that success is possible.

Specifically, with women entrepreneurs, Shettar (2020) assures that "women entrepreneurship is the process in which women initiate a business, gather all resources, undertake risks, face challenges, provides employment to others and manages the business independently" (p. 3843). In this sense, the essential ingredients of women entrepreneurship identified by Shettar (2020) are self Belief, Ambition, passion and persistence, humility, and willingness to learn, hard work, clarity of thought, and a firm drive, constant investment in learning.

Byrne et al., (2019) identify 4 types of women entrepreneurs: individualized, maternal, relational, and excessive - highlighting the diversity of women in terms of how they "do" entrepreneurship. These different types are not equally valued, and a hierarchical relationship exists between different modes of femininity, as shown in Table 1. 
Table 1. Entrepreneurial Femininities

\begin{tabular}{|c|c|}
\hline $\begin{array}{l}\text { Individualized } \\
\text { Entrepreneurial } \\
\text { Femininity: } \\
\text { Entrepreneur }\end{array}$ & $\begin{array}{l}\text { Women entrepreneurs doing "individualized } \\
\text { entrepreneurial femininity" } \\
\text { - Being active, dynamic individuals who overcome any } \\
\text { restrictions theymay encounter. } \\
\text { - They are strongly individualist. } \\
\text { - Distance themselves from the practice and traits of } \\
\text { traditional femininity but continue to enact both masculine } \\
\text { and feminine characteristics (combination necessary). } \\
\text { - Actively separate their domestic and public spheres } \\
\text { (active detachment from home/managing association } \\
\text { within the domestic private world of home and work so } \\
\text { that it does not interfere with their business-this shows } \\
\text { an understanding of gender rules). } \\
\text { Believe that entrepreneurship is gender neutral. Woman is } \\
\text { a freely choosen subject; males and females have an equal } \\
\text { chance to succeed if they are ambitious and hardworking; } \\
\text { women are no longer oppressed. Entrepreneurship is } \\
\text { meritocratic: Doing business impliesabiding by universal } \\
\text { standards of good business practice. } \\
\text { Have to be careful of being too masculine in the way they } \\
\text { dobusiness. }\end{array}$ \\
\hline $\begin{array}{l}\text { Maternal } \\
\text { Entrepreneurial } \\
\text { Femininity: } \\
\text { Mumpreneur }\end{array}$ & $\begin{array}{l}\text { Women entrepreneurs doing "maternal entrepreneurial } \\
\text { femininity." } \\
\text { - Create their own life in similar ways to their male } \\
\text { colleagues whilemaintaining a foothold in the domestic } \\
\text { domain. } \\
\text { - Are mothers who seek independence and self-reliance } \\
\text { through entrepreneurship. } \\
\text { - Establish an explicit link between motherhood and } \\
\text { entrepreneurial activities: offer a product or service } \\
\text { associated with family or motherhood (mumpreneur); } \\
\text { operate in the home and/or at the "school gate". } \\
\text { Connects to women's traditional caring responsibilities } \\
\text { of lookingafter home and children: what work can they } \\
\text { do while caring for children. } \\
\text { Incorporates both masculine and feminine aspirations; } \\
\text { is progressive but still reassuringly feminine. } \\
\text { Experience limits on their participation in the business } \\
\text { world: domestic and childcare responsibilities create } \\
\text { tensions and may limitentrepreneurial endeavors. }\end{array}$ \\
\hline $\begin{array}{l}\text { Relational } \\
\text { Entrepreneurial } \\
\text { Femininity: Female } \\
\text { Entrepreneur }\end{array}$ & $\begin{array}{l}\text { Women entrepreneurs doing "relational entrepreneurial } \\
\text { femininity." } \\
\text { - Recognize and place value on the skills, attributes, and } \\
\text { leadership styles associated with women; trust in } \\
\text { "feminine management", believe that women have a } \\
\text { special contribution to make; uniquely feminine } \\
\text { viewpoint; contrast to the masculine character of }\end{array}$ \\
\hline
\end{tabular}




\begin{tabular}{|c|c|}
\hline & $\begin{array}{l}\text { managing and organizing; believing in complementarity } \\
\text { of sexes. } \\
\text { - Adopt a transformational leadership style implying } \\
\text { power sharing; promoting trust relations with } \\
\text { employees. } \\
\text { - } \quad \text { Pursue collective goals as opposed to individual ones. } \\
\text { - Reject management strategies that impose a divide } \\
\text { between home and business and argue for an equal } \\
\text { balance (but not primarily concerned with conciliating } \\
\text { motherhood and entrepreneurship) } \\
\text { - Challenge dominant assumptions of what it is to be a } \\
\text { successful entrepreneur. } \\
\text { - Reject masculine, growth-oriented orientation to } \\
\text { business; advocatesmall and stable business. } \\
\text { - Place great emphasis on relational interaction, mutual } \\
\text { empathy, andmutual empowerment in doing business. } \\
\text { Activate (or compensate for) masculinity by drawing on } \\
\text { a discourseof professionalism to retain credibility and } \\
\text { counterbalance their distance themselves from the } \\
\text { male norm of entrepreneurship to demostrate that they } \\
\text { embrace values of a competitive world to emphasize } \\
\text { the value of female traits and attributes in business but } \\
\text { also need to avoid being "too feminine." }\end{array}$ \\
\hline $\begin{array}{l}\text { Excessive } \\
\text { Entrepreneurial } \\
\text { Femininity: Non- } \\
\text { preneur }\end{array}$ & $\begin{array}{l}\text { Women entrepreneurs doing "excessive entrepreneurial } \\
\text { femininity." } \\
\text { - Displays the wrong amount and wrong kind of } \\
\text { - Eemininity within abusiness context. } \\
\text { Engage in unnecessary or unwarranted feminine } \\
\text { displays. } \\
\text { Enacts traditional femininity (dependence; } \\
\text { vulnerability; passivity; aneed for male approval), } \\
\text { which prevents her from fulfilling her ambitions and } \\
\text { achieving entrepreneurial success. } \\
\text { - Fail to compensate for their stereotypical } \\
\text { feminine behavior by drawing on other } \\
\text { masculine norms in entrepreneurship. } \\
\text { - Are perceived as illegitimate, "non-preneurs" } \\
\text { Are rejected due to their perceived shortcomings. } \\
\text { Structural or cultural constraints-or their minority } \\
\text { presence in the ranks of entrepreneurs-are not } \\
\text { to blame. They are to blame for their own } \\
\text { exclusion from the entrepreneurial field. }\end{array}$ \\
\hline
\end{tabular}

Source: Byrne, et al (2019, pp. 2-3).

Additionally, Byrne et al., (2019) takes up the distinctive aspect of motivation for fun that characterizes female entrepreneurship and proposes a new feminine entrepreneurial identity, "fun-preneurs" (mentioned in the first section). Describe it as women who stressed 
entrepreneurship as "a source of pleasure and enjoyment, an avenue for them to channel their strengths and interests (passions) while enjoying a good quality of life (adventure, fun)" (p. 23). In this sense, the authors propose five entrepreneurial femininities that they identified in role models' narratives, presented in Figure 4.

Figure 4. Role Models and Women Entrepreneurs Five Entrepreneurial Femininities

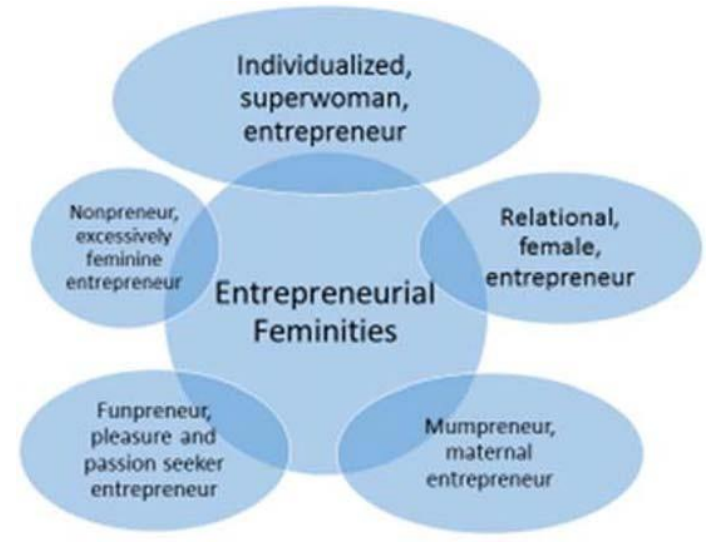

Source: Byrne et al. (2019, p. 24).

\section{Family-Business Balance: A Gender Perspective}

The family is one of the most important aspects of human development. It is in the family sphere, where the values, habits, customs, lifestyle, and almost every aspect of our identity in adult life are developed. The impact of the family on different facets of the human being has been widely studied; such is the case of the entrepreneurial phenomenon (Aldrich \& Cliff, 2003; Baron, 2002; López-Fernández et al., 2016; Santamaría et al., 2013; Singh \& Sebastian, 2018). Since the beginning of studies on entrepreneurship, the relevant role of the family has been recognized (Aldrich \& Cliff, 2003; Singh \& Sebastian, 2018).

The family's influence on the entrepreneurial phenomenon is not limited to the psychological and personal sphere, but also contributes to the development of social conditions that, together with culture and the educational system, are key variables for the development of entrepreneurial human capital (Kantis et al., 2020).

According to Kantis et al. (2020), social conditions are a consequence of the profile of the families where entrepreneurs were born and grow and have a significant influence on the formation of values and attitudes related to entrepreneurial behavior.

On the other hand, the most important area for women in the social and cultural aspects is family. Women's responsibilities in the family context are often much more demanding than for men. This has made women's entrepreneurship distinctive and faces challenges bigger than men's, with their family's support being one of these aspects. 
Woman faces greater challenges in carrying out a business initiative. First, they must assume a variety of roles in their family, home, and business environment. Unlike the male gender, women are expected to assume most of their family responsibilities and as a result, it is very relevant to deeply understand the two-way effect of family and work on the development of women's entrepreneurial spirit (Neneh, 2017).

In management, there is extensive research on work-family interaction, which focuses on the perspective of conflict; it is assumed that people must assume multiple roles frequently in contra posed which causes them social-psychological mismatches (Jiménez y Gómez, 2015). However, recognizing that conflict exists, a perspective has recently been incorporated that has investigated the positive interdependence of family and work domains with the aim of analyzing the phenomenon from a positive psychology perspective (Greenhaus et al., 2003). Thus emerges the concept of work-family balance, whose definitions present common elements, derived mainly from the notion of balance, or not balance, between experiences in the work role and the family role (Eddleston \& Powell, 2012; Greenhaus \& Powell, 2006; Grzywacz \& Butler, 2005) We consider that the enrichment between work and family, such as the conflict between work and family, is two-way. Enrichment from work to family occurs when work experiences improve the quality of family life, and family-to-work enrichment occurs when family experiences improve the quality of working life.

In line with this view, Greenhaus \& Powell (2006) declare that experiences in the family can improve the quality of life in entrepreneurial work. They also considered that the quality of roles (in family and work context) has two components: high performance and positive partnerships. They propose that the resources generated in one role have a positive impact on the other, and this relationship is conditioned on the relevance of the resource.

A resource is an asset that can be developed in the execution of roles when needed to resolve a problem or deal with a challenging situation. Resource generation is a crucial driver of the familyto-work relationship enrichment process and the characteristics of roles and personal characteristics are likely to determine the extent to which they are integrated (Greenhaus and Powell, 2006).

\section{Challenges of female entrepreneurship in the Latin American}

According to the GEM, Latin America and Africa are the world's regions with the highest levels of entrepreneurial intention (Bosma \& Kelley, 2018). The average for total female entrepreneurial activity (age 18 to 64 ) in Latin America and the Caribbean is $17 \%$. However, the region also has the lowest average female growth expectations (Kelley et al., 2017).

Likewise, Bojórquez et al., (2019) state that in Mexico 48\% of micro-businesses are run by men and $52 \%$ by women. Considering these micro-businesses run by women, it can be distinguished that the majority (52\%) correspond to the economic activity of commerce, followed by the economic activity of service (31\%), On the other hand, in micro-businesses run by men, there is a greater distribution among the activities carried out, the main activity being service (35\%); followed by the commerce sector with $27 \%$ of micro-businesses.

According to Gutiérrez et al. (2020) Latin American women become entrepreneurs in order to have flexibility and independence because of the lack of job opportunities and the need to bring a livelihood to their homes and consequently with this, statistics in Mexico show that there is an increasing number of women who become "heads of the family" and providers of the 
sustenance of their children, this due to the propensity of the increase of women with children without a partner (28.3\% in the first quarter of 2018), single women (with $9.2 \%$ ) and breakups spouses divorced (2.5\%), separated (6.4\%) and widows (10.2\%) (Gutierrez et al., 2020)

From these statistics, it is important to highlight that the concept of "head of the family" comes from a heteropatriarchal discourse that considers the male partner as the highest authority of the family and whose character does not need explanation, since it is subscribed to a supposed natural and biological order. For this reason, only single women are considered for counting female heads of household but with a broader criterion, it can be estimated that the number of women who support households is greater.

Although Latin American female entrepreneurship faces similar challenges in other parts of the world, such as lack of financing, concentration in low-growth sectors, lack of education and training in companies; it has been developed and consolidated as an option for the development of many women as the previous figures from GEM, Grupo Banco Mundial, and OECD showed.

The barriers described by Raghuvanshi et al., (2017) that impact the female entrepreneurship capacity are observed in practically all regions of Latin America. Figure 5 integrates them as restrictive forces of female entrepreneurship and contrasts them with the driving forces that promote it, which have been discussed in this theoretical framework but highlighting those that were considered with the greatest incidence in Latin America according to their particularities.

The family is fundamental in the Latin American female context. Therefore, is the aspect on which the model is based (see figure 5). As the previously cited studies point out, women who separate from their partners and have children become "heads of the family", the most important economic and social breadwinner in the family, and the flexibility provided by independent work makes entrepreneurship a feasible and affordable development option to support yourself and take care of your children or family members. The figures previously presented that indicate the growth of female entrepreneurship in Latin America supports this hypothesis. (Bosma et al., 2021; Fareed et al., 2017; OECD, 2018).

Family is the driving force for many Latin American women entrepreneurs. It is their motivation to move forward and to overcome the restrictive barriers. The first one is their exclusion from male spheres that limit their professional development, such as being in productive sectors considered masculine, like construction, mechanics, and areas of engineering and technology. The second one is labor discrimination, which occurs due to the lack of confidence in women's abilities for work; an example of this are dismissals due to pregnancy or that they are hired for simple jobs for fear that they will fail to comply for the time they require to care for their children. Another restrictive barrier is the lack of institutional support, since business environments are more favorable for men and do not consider women's restrictions to access them. Finally, another aspect is the family responsibilities in taking care of children that are usually for women.

According to this model, if women have support and can manage to overcome these restrictive forces, they develop their entrepreneurial style and empower them to realize their starts up so female entrepreneurship can display. 
Entrepreneurship contributes to developing self-confidence in women and being a proposal for society to recognize their work. This is how the empowerment achieved by women through their entrepreneurial initiatives contributes to reducing the gender gap and thus a more just society.

Figure 5. Driving and restraining forces of female entrepreneurship:

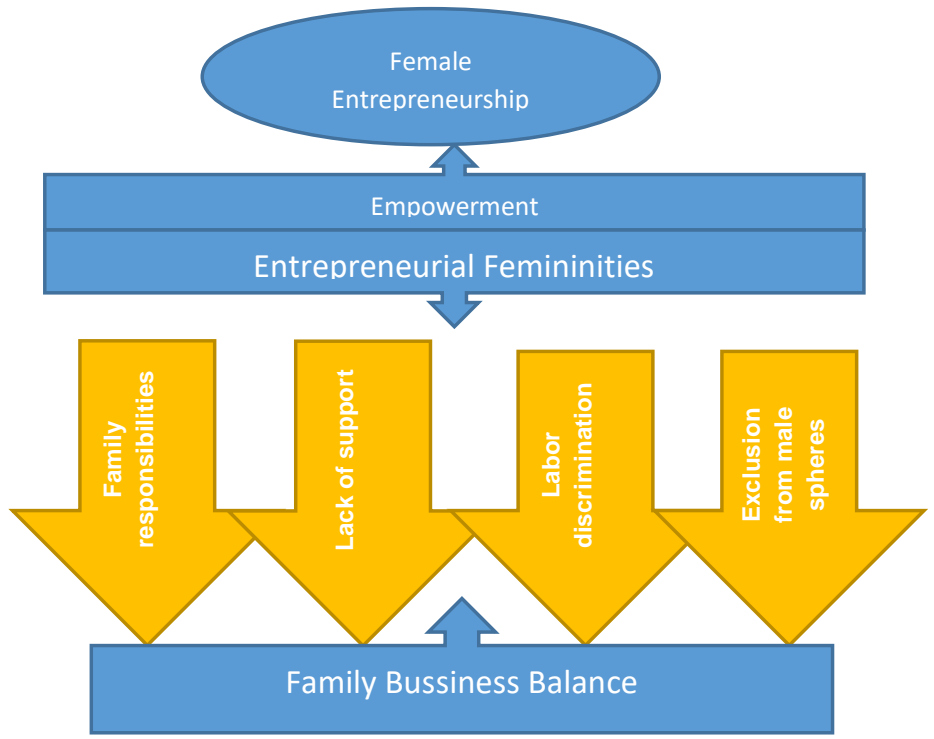

Source: Own elaboration.

This model contributes to the study of family-business dynamics with a gender focus. The gender approach has a whole school of study in Latin America, mainly because of the role of women in society and its limitations for their professional development.

However, Latin American female entrepreneurship studies have focused on illustrating the differences concerning men and women in management, entrepreneurial orientation, barriers to their development. It seems that the causes that originate this situation have been left aside, as is their family role.

Likewise, most academic publications on entrepreneurship do not include the Latin American perspective. For example, most of the bibliometric studies on entrepreneurship that were reviewed found that between 80 and 90 percent of the work came from North America, Europe, and Asia. In fact, the Asian region has significantly increased its academic publications on this subject (Indarti et al., 2020; López-Fernández et al., 2016; Pato and Teixeira, 2014; Servantie et al., 2016; Velt et al., 2020).

Academic contributions are needed to describe the entrepreneurial phenomenon in the Latin American context. Pointing out its restraining and motivating forces for a better understanding and is what this work contributes to. 


\section{Methods}

This work presents two cases of Latin American female entrepreneurs who assume their female roles and try to balance them with their business roles. It provides data and information that contributes to understanding the reality of the women's environment in the field of business, their challenges, limitations, opportunities, and the problems faced with their families. Their life stories are analyzed trying to achieve synchronous analysis according to critical realistic analysis that allows understanding their situation as the result of realities, relationships, and processes.

We undertook a qualitative study consisting of semi-structured, in-depth interviews with 2 women entrepreneurs based in México y Ecuador. Capturing participant perceptions of entrepreneurship, and whether discursive expectations and policy objectives are realistic is possible through interpretive methods such as interviews (Dy \& Agwunobi, 2018).

Researchers such as Dy and Agwunobi (2018) argue that a narrative or life history approach to data collection encourages participants to share a broad vision of what they perceive and what shapes their life experiences. This, combined with thematic analysis, can provide a better understanding of drivers, barriers, and limitations presented in the cases under study and are relevant to the objectives of this research.

\section{Results}

Two cases are presented. The first Mrs. Lucia, an adult woman, divorced and who is dedicated to elaborating handmade dolls and working on her own in design; all combined with her domestic work. Subsequently, the case of Mrs. Veronica, an adult woman, divorced, dedicated to the sale of travel services. To complete her income, selling children's clothing. She defined herself as an independent, enterprising woman.

Both cases illustrate the Driving and restraining forces of female entrepreneurship face in Latin America because of their gender status in the business field and the challenges they face to achieve harmony between their family and business roles.

\section{Case 1. Mrs. Lucia. Artisan, Mexican.}

Lucía has 44 years. She was born in Mexico City but has lived in several states of the Mexican republic. She has already lived in the city of Merida, Yucatan for 10 years. Her parents are teachers, already retired.

She defines herself as "happily divorced" is an independent woman free of social conventionalisms. She has two children, ages 22 and 14, and she affords the household expenses.

Lucia has undergraduate studies in graphic design and communication currently completes a master's degree online to have time availability. Works independently for advertising agencies. She was employed for 9 years but due to her motherhood, decided to give up her job and work independently from home. She explains that it is very difficult to work on his own, since many times customers take a long time to pay or simply do not pay. She lives with her sons and does not have family support, so she cannot take a full-time job. The ups and downs of his independent work made it always her mind to open a business to improve her income.

She remembers that four years ago, he came up with the idea of making a doll with an old sock, like a Sock Monkey doll, which is popular in the United States but not known in México. 
She decided to look for through the internet how to make them. She worked very hard to make that first doll but found very relaxing the brewing process and decided to do it as anti-stress therapy.

While her children were playing sports, she took her materials and occuped that time making those sock-based dolls. The other mothers waiting for their children began asking her about the dolls and suggested selling them. That is how she started making dolls with socks to sell.

Lucia mentions that in her childhood she suffered from asthma and her parents did not allow her to have stuffed dolls, nor fabric dolls, so, in a way, this business allows her to fill that need that in her childhood could not satisfy. She also mentions that it is very satisfying to see that his creations are appreciated and manage to establish emotional bonds with his clients. In addition, being made with socks and washable poses no danger to children, nor those with asthma.

To make sense of his business idea, he gave it a name that is currently registered as a trademark at the Mexican Institute of Industrial Property. She produces several products such as artisanal lines, children, yogi, zombies, etc. With her advertising knowledge, she has managed to provide identity to her creations and sells them as unique and unrepeatable, and motivates his buyers to create stories for them. It advertises and sells through Facebook and Instagram and shares stories of a doll that is pet and company image. This infects its customers, who also share photos of their dolls in different activities and places.

She develops her entrepreneurship in her way and without family support. She mentions that her children, sometimes at the beginning of her business, accompanied her to carry out her activities but are not currently related to the business.

The distribution is through bazaars and tianguis (a small market that is installed periodically on the street). She does not have a point of sales permanently, as it keeps production volume at a level with which she can continue to work in advertising independently.

Lucia likes to face challenges and likes to develop new dolls and gives them personality. She also establishes alliances with other entrepreneurs to make the clothes of the dolls. She has the idea that your company can grow and manages to hire women in rural areas to make the products.

According to her point of view, the context where she lives is patriarchy, in which many women think "I've already married, now I do not have to work because my husband supports me and my kids" and that makes them dependent on their husbands. Doña Lucia thinks that it is necessary to break with the scheme. She argues that her products are an alternative to providing work for women, as they can make them at home without neglecting their children.

She mentions that if she could, she would work harder for her company and probably would grow. For example, she cannot spend a lot of time on social media and cannot hire someone to do it because her income is not secure. She says if I have more capital, I would work on what I really enjoy doing the two activities, but not taking so many projects to have more time for myself.

\section{Case 2. Mrs. Veronica, Trader, Ecuadorian.}

Mrs. Veronica, 37, originally from the city of Quito, resides in the city of Riobamba 14 years ago, her father is retired from the national police, and her mother is a housewife. 
She is a divorced woman and has two daughters, 17 and 7 years old. She takes care of and supports her daughters. She is an independent, enterprising woman with economic freedom. She has a bachelor's degree in tourist management. She works independently at her travel agency and in the sale of children's clothing. Twelve years ago, decided to start up a business because of the need to devote time to her daughters and earn higher incomes for her family. Explains that business innovation is the key to permanence over time and achieving profits.

She lives with her two daughters and has the support of her parents for childcare. Since she opened her business, she has not taken days off because she is the only breadwinner of her family. However, she feels in control of your life and time. In his words: "Owning only a minimum wage encourages you to start a business by considering that you own your time and that the effort you make is entirely for you, not for other people's business."

She recounts that his business has changed over time, started with the sale of household lingerie, evolved to the sale of handicrafts, dried flowers; integrated into the business the distribution of hair extensions, beauty products, implemented for the sale of children's clothing and the sale of auto insurance.

Additionally, eight years ago, she created a travel agency, which over time became her principal economic activity. Mrs. Verónica works very hard to grow her business, she said: "business depends only on you", in this way shows her distrust in the environment and little willingness to delegate functions. As a management professional, she is aware of the importance of the legal protection of her brand, especially in the Ecuadorian context, so she registers the travel agency's brand with the Ecuadorian Institute of Intellectual Property, the Superintendency of Companies, and the Ministry of Tourism of Ecuador. She is also in charge of digital marketing strategy and advertises her business through social media like Facebook, Instagram, and WhatsApp. She emphasizes, "the important thing in the business is that people recognize your name. In this way, people from nearby cities are looking for you to provide them with the service of selling tourist packages". She also sells tourist packages directly to the final customer.

Ms. Verónica has the support of her mother in her domestic work and childcare responsibilities, and she points this out as fundamental to carry out her company and achieve its growth and consolidation. She also counts on her daughter's support in the business. She believes that girls must learn to be entrepreneurs, learn to be free, and work hard to earn money for food, so they learn to create work for more women and others.

From her point of view, entrepreneurship goes from generation to generation; you learn in the family environment, getting an income is valued in the new generations as a culture so that you do not depend on anyone, neither emotionally nor economically, you get savings and take advantage of every moment and the last penny to work and invest. Ms. Verónica has the support of her mother in her domestic work and childcare responsibilities, and she points this out as fundamental to carry out her company and achieve its growth and consolidation. She also counts on her daughter's support in the business. She believes that girls must learn to be entrepreneurs, learn to be free, and work hard to earn money for food, so they learn to create work for more women and others.

From her point of view, entrepreneurship goes from generation to generation, to learn in the family environment, getting an income is valued in the new generations as a culture so that 
you do not depend on anyone, neither emotionally nor economically, get savings and take advantage of every moment and the last penny to work and invest.

She considers that the biggest obstacles as an entrepreneur in her context are government persecution of people who disagree with state policies, lack of flexible hours to hire workers; interest rates on credits reach up to $18 \%$, which is quite expensive; taxes on social media advertising, taxes of $2 \%$ before sales, coupled with the payment of rents, workers' salaries, bank commission for the transfer of money, make the products and services offered by microentrepreneurs more.

She thinks that women can start businesses on their own, even without family support but It is necessary to have in mind that business is not for women or men,

but for those who want to take risks. In addition, government support with low-interest rate credits is indispensable.

She argues that machismo is rooted in Ecuadorian society; suppliers want to exceed supply prices because you are a woman. Besides, the idea remains that "man knows about cars, women know pots", and when you go to the mechanics to fix your car, you change the parts, overcharging and scam only for the fact that you are a woman. It suggests that learning more from other areas, such as mechanics, makes treatment equitable, so that we are representative of Ecuadorian society and men see us differently and respect us.

\section{Discussion}

In both cases, divorced women are represented who do not have the support of their male partners to raise their children. Therefore, they focused on developing productive activities with the flexibility of time to face their responsibilities, as reported in the study by Gutiérrez et al. (2020), which largely explains the great insertion of women entrepreneurs in the Latin American region.

In both cases, the barriers pointed out by Raghuvanshi et al., (2017) are also illustrated, such as lack of financing, time limitations for maternity, and lack of support from their male partners. Likewise, they concentrate their work in sectors of design and tourism services that are not properly associated with the masculine.

In the second case, the entrepreneur receives psychological, emotional, and financial support from her parents, which has led to her developing this activity throughout her life and even with repercussions on her physical well-being, which is consistent with what was stated by Greenhaus \& Powell (2006) y Neneh (2017).

Also, it is observed that these two female entrepreneurs maintain their enterprises at a low level, they do not want their companies to grow to have time for their families, which according to Marlow (2002), in the sense that the low growth of women's businesses are due to social representations associated with femininity, since their main role is at home and not in work. This is also in congruence with the entrepreneurial femininities described by Byrne et al., (2019). In both cases, it is possible to observe relational entrepreneurial femininity characteristics, called female entrepreneurs, where leadership with a feminine style is assumed, and they embrace values of a competitive world, emphasizing values of female traits and attributes in business.

The first case (Doña Lucia) can also be seen as a fun-preneur, and this conception of her company as a hobby is her main limiting force. In fact, she sees as "serious" her work as an independent designer and her artisan startup as her hobby. 
Continuing with the analysis and taking the ideas of Jiménez y Gómez (2015), both businesswomen see their micro-enterprises as a system connected to their family system so that the decisions of one area are connected to the other and develops multiple roles in contra posed which causes them social-psychological mismatches.

The cases presented are women without the support and the economic responsibility of taking care of their family, who decide to offer professional services as independent workers. These ventures confirm the studies by Eddleston \& Powell (2012); Greenhaus \& Powell (2006); Grzywacz \& Butler (2005) regarding the fact that achieving work-family balance and flexibility are important triggers for women's businesses.

Likewise, this situation fits with what Marlow (2002) raises, in the sense that anthropocentric society causes restrictions on women in constructing their economic and social capital. Their male partners do not fully assume the economic and physical costs of upbringing, being women who assume them, limiting their development in the professional field.

These women entrepreneurs face exclusion due to their status as women, for assuming their motherhood without male support, being a divorced woman in a traditional society, lack of money for their housework, all at the same time and at different levels, which illustrates intersectionality.

Although this lack of support limited their employment options, it was what paradoxically triggered their ventures as independent professionals and both with ventures in secondary areas, to supplement their income. This multitask approach may be characteristic of Latin American women who face restrictions due to their gender conditions, when living in developing countries, face serious monetary restrictions, probably more intensely than their counterparts in developed countries.

Another aspect that can be highlighted is that in both cases, the entrepreneurial women who start these businesses are empowered and did not allow themselves to be defeated by the fact of being alone and facing social exclusion due to their status as divorced. It seems that the desire to raise their children is their greatest motive and what inspired the model presented in figure 5 .

Cases like these of Lucía and Verónica, small businesswomen in Ecuador and Mexico illustrate Shettar (2020) results about empowerment. These women were able to find in entrepreneurship a way to fulfill themselves and be independent, including control over resources and ideology, which allow increasing their self-confidence.

In this sense, entrepreneurship can be an important tool for women's empowerment, since it could help bring gender equality and improve their economic situation since it gives them a job option under their control and can allow them to balance their female roles.

As Asfiah et al., (2018) declares women entrepreneur play a key role to economic resilience, and both cases illustrate it

\section{Conclusions}

The document offers a theoretical basis that integrates an evaluation of the drivers and restrictive forces of female entrepreneurship in Latin American.

Additionally, it considers the effects of general intersecting structures such as gender, marital status, and socioeconomic class and presents empirical evidence through which these 
socio-structural influences, and the degree of their impact, can be identified and their influence analyzed on the essential aspects of the entrepreneurial activity of Latin American women In this regard, the article exposes that Latin American women entrepreneur face multiple barriers to starting and consolidating their businesses. According to the theoretical review and the empirical findings, the most important are:

- Exclusion from male spheres.

- Labor discrimination

- Lack of support

- Family responsibilities

These were integrated as restrictive forces of Latin American female entrepreneurship (see figure 5). Likewise, the advancement in the state of art shows the empowering effect of entrepreneurship in the female context, which could be verified and illustrated in the cases analyzed in this work.

Additionally, considering that family constitutes one of the main supports for entrepreneurship, this work proposes the family-business balance as the basis to encourage female entrepreneurship, given the importance of the family in the Latin American cultural context (see figure 5).

The social role of women makes the support of their family to carry out productive activities and enterprises are very important. Likewise, this social role can limit their opportunities in the workplace and business, so it is necessary to expand the existing knowledge of women's companies to avoid trying to fit it into patterns of male companies and consider them as references to evaluate their performance. So we analyzed and applied the framework of entrepreneurial femininities from Byrne et al., (2019). We observe that the cases analyzed in this work are consistent with the relational model, which implies empowerment by recognizing female differences but empowering women entrepreneurs to more equitable changes in their business society.

The cases presented also illustrate that families can support women's businesses economically and emotionally, which is expressed in offering time and money to carry out business activities.

The women who were interviewed for this article achieved the motivation to carry out their companies based on their desire to balance their motherhood with their professional development. In both cases, they do not have the support of their children's father for family expenses. This situation leads them to start up a business, to survive, and as professional development. It provides them with independence, empowerment, but the lack of institutional support and their male peers are seen as their main barriers to growth.

The opportunities for studying the entrepreneurial phenomenon in the Latin American context with a gender perspective are enormous given our tradition of gender studies and the potential for the economic contribution of female entrepreneurship. It is the task of us researchers to generate studies to discuss, disseminate and generate innovative knowledge on this theme.

\section{Bibliographic References}

Ahl, Helene (2006). Why Research on Women Entrepreneurs Needs New Directions.

Entrepreneurship: Theory and Practice, 30, United States. (Pp.595-622). https://doi.org/10.1111/j.1540-6520.2006.00138.x 
Aldrich, Howard E.; Cliff, Jennifer E. (2003). The pervasive effects of family on entrepreneurship: Toward a family embeddedness perspective. Journal of Business Venturing, 18 (5), Países Bajos. (Pp.573-596). https://doi.org/10.1016/S0883-9026(03)00011-9

Asfiah, Nurul; Anshori, Muslich; Mawardi, Imron. (2018). An Analysis of Women Empowerment on Micro Business with Social Entrepreneurship Concept. Advances in Social Science, Education and Humanities Research, 231, France (Pp.67-70). http://repository.unair.ac.id/101350/1/Imron Mawardi_Karil 45_An Analysis of Women.pdf

Baron, Robert. (2002). OB and entrepreneurship: The reciprocal benefits of closer conceptual links. Research in Organizational Behavior, 24, Países Bajos. (Pp.225-269). https://doi.org/10.1016/S0191-3085(02)24007-1

Bojórquez, Ana; Suárez-Núñez, Tirso; Flores-Novelo, Anel (2019). Microempresas femeninas y la contribución de las TIC a su desarrollo. Fontamara. México.

Bosma, Niels, \& Kelley, Donna. (2018). GEM Global Entrepreneurship Monitor 2017/2018.

Global Report Extraído de https://www.gemconsortium.org/file/open?fileld=50213

Bosma, Niels, Hill, Stephen, Ionescu-Somers, Aileen, Kelley, Donna, Guerrero, Maribel, \& Schott, Thomas. (2021). GEM Global Entrepreneurship Monitor: 2020/2021. Global Report.

Extraído de https://www.gemconsortium.org/file/open?fileld=50691

Byrne, Janice; Fattoum, Salma; Diaz Garcia, Maria Cristina. (2019). Role Models and Women Entrepreneurs: Entrepreneurial Superwoman Has Her Say. Journal of Small Business Management, 57 (1), United States. (Pp.154-184). https://doi.org/10.1111/jsbm.12426

Drencheva, Andreana. (2019). Women entrepreneurs and wellbeing: An identity perspective. In Lepeley, Maria-Teresa; Kuschel, Katherina; Beutell, Nicholas; Pouw, Nicky; Eijdenberg, Emiel (Eds.) The Wellbeing of Women in Entrepreneurship: A Global Perspective. Routledge. England. (Pp. 280-294). https://doi.org/10.4324/9780429279836

Dy, Angela; Agwunobi, Adaku Jennifer (2018). Intersectionality and mixed methods for social context in entrepreneurship. International Journal of Entrepreneurial Behaviour and Research, 25 (8), United Kingdom. (Pp.1727-1747). https://doi.org/10.1108//JEBR-12-2017-0498

Eddleston, Kimberly A.; Powell, Gary N. (2012). Nurturing Entrepreneurs' Work-Family Balance: A Gendered Perspective. Entrepreneurship: Theory and Practice, 36 (3), United States. (Pp.513-541). https://doi.org/10.1111/j.1540-6520.2012.00506.x

Fareed, Fozan; Gabriel, Mabel; Lenain, Patrick; Reynaud, Julien (2017). Financial Inclusion and Women Entrepreneurship: Evidence from Mexico. OECD Economics Department Working papers, 1411. France. https://doi.org/10.1787/2fbd0f35-en

Gálvez P., Thelma (2001). Aspectos económicos de la equidad de género. Serie Mujer y Desarrollo de la CEPAL, 35. Naciones Unidas. Chile. Extraído de https://www.cepal.org/sites/default/files/publication/files/5882/S01060530_es.pdf

Greenhaus, Jeffrey H.; Collins, Karen, M.; Shaw, Jason D. (2003). The relation between workfamily balance and quality of life. Journal of Vocational Behavior, 63 (3), Países Bajos. (Pp.510-531). https://doi.org/10.1016/S0001-8791(02)00042-8 
Greenhaus, Jeffrey H.; Powell, Gary N. (2006). When work and family are allies: A theory of workfamily enrichment. Academy of Management Review, 31 (1), United States. (Pp.7792). https://doi.org/10.5465/AMR.2006.19379625

Grupo Banco Mundial (2018). Mujer, Empresa y el Derecho 2018. Grupo Banco Mundial. Estados Unidos. Extraído de https://thedocs.worldbank.org/en/doc/6639715323807569320050022018/original/WBL2018KeyFindingsSpanish.pdf

Grzywacz, Joseph. G.; Butler, Adam B. (2005). The impact of job characteristics on work-tofamily facilitation: Testing a theory and distinguishing a construct. Journal of Occupational Health Psychology, 10 (2), United States. (Pp.97-109). https://doi.org/10.1037/1076-8998.10.2.97

Gurría, Angel. (2018). Palabras del Secretario General de la OCDE en la Apertura del Seminario Interactivo sobre Mujeres Emprendedoras OCDE-INADEM. Organización para la Cooperación y el Desarrollo Económico (OCDE). Ciudad de México, México. Extraído de https://www.oecd.org/about/secretary-general/oecd-inadem-interactive-workshopon-women-entrepreneurs-mexico-2018-sp.htm

Gutiérrez Cruz, Merlyn; Such Devesa, María Jesús; Gabaldón Quiñones, Patricia (2020). La mujer emprendedora en el turismo rural: peculiaridades del caso costarricense a través de la revisión bibliográfica. Cuadernos de Turismo, 46, España. (Pp.185-214). https://doi.org/10.6018/turismo.451691

Henry, Colette; Foss, Lene; Ahl, Helene (2016). Gender and entrepreneurship research: A review of methodological approaches. International Small Business Journal, 34 (3), United States. (Pp.217-241). https://doi.org/10.1177/0266242614549779

Indarti, Nurul; Hapsari, Naya; Lukito-Budi, Andy Susilo; Virgosita, Risa (2020). Quo vadis, ethnic entrepreneurship? A bibliometric analysis of ethnic entrepreneurship in growing markets. Journal of Entrepreneurship in Emerging Economies, United Kingdom. https://doi.org/10.1108/JEEE-04-2020-0080

Jiménez Figueroa, Andrés; Gómez Urrutia, Verónica. (2015). Conciliando trabajo-familia: análisis desde la perspectiva de género. Diversitas: Perspectivas en Psicología, 11(2), Colombia. (Pp.289-302). https://www.redalyc.org/pdf/679/67944781009.pdf

Kantis, Hugo; Federico, Juan; Ibarra García, Sabrina; Fernández, Cristina (2020). Índice de condiciones sistémicas para el emprendimiento dinámico: Mas allá de la pandemia. Universidad Nacional General Sarmiento. Prodem. GEN. Argentina. http://www.rfd.org.ec/biblioteca/pdfs/LG-255.pdf

Kelley, Donna J.; Baumer, Benjamin S.; Brush, Candida; Greene, Patricia G.; Mahdavi, Mahnaz; Majbouri, Mahdi; Cole, Marcia; Dean, Monica; Heavlow, Rene. (2017). Women's Entrepreneurship 2016/2017 Report. Global Entrepreneurship Monitor. United States. $\quad$ https://www.gemconsortium.org/report/gem-20162017-womensentrepreneurship-report

La Barbera, MariaCaterina (2016). Interseccionalidad, un "concepto viajero": orígenes, desarrollo e implementación en la Unión Europea. Interdisciplina, 4 (8), México. (Pp.105-122). http://dx.doi.org/10.22201/ceiich.24485705e.2016.8.54971

Laguía, Ana; García-Ael, Cristina; Wach, Dominika; Moriano, Juan A. (2018). "Think entrepreneur - think male": a task and relationship scale to measure gender stereotypes 
in entrepreneurship. International Entrepreneurship and Management Journal, 15. United States. (Pp. 749-772). https://doi.org/10.1007/S11365-018-0553-0

Lázaro Castellanos, Rosa; Jubany Baucelis, Olga. (2017). Interseccionalidad del género y mercado de trabajo postfordista. La ventana: Revista de estudios de género, 5 (46), México. (Pp. 202-243). http://www.scielo.org.mx/scielo.php?pid=S140594362017000200202\&script=sci_abstract

Lin, Ting-Ling; Lu, Tzu-Ying; Hsieh, Mei-Chen; Liu, Heng-Yih (2018). From conception to startup: Who and what affect female entrepreneurship. Contemporary Management

Research, 14 (4), Taiwan. (Pp.253-276). https://doi.org/10.7903/cmr.17957

López-Fernández, María Concepción; Serrano-Bedia, Ana María; Pérez-Pérez, Marta. (2016).

Entrepreneurship and Family Firm Research: A Bibliometric Analysis of An Emerging

Field. Journal of Small Business Management, 54 (2), United States. (Pp.622-639). https://doi.org/10.1111//ssbm.12161

Marlow, Susan (2002). Women and Self-Employment: A Part of of Apart from Theoretical Construct? The International Journal of Entrepreneurship and Innovation. United States. (Pp.83-91). https://doi.org/10.5367/000000002101299088

Mirchandani, Kiran (2002). Feminist Insight on Gendered Work: New Directions in Research on

Women and Entrepreneurship. Gender, Work \& Organization, 6 (4), UK. (Pp. 224235). https://doi.org/10.1111/1468-0432.00085

Neneh, Brownhilder Ngek. (2017). Family Support and Performance of Women-owned Enterprises: The Mediating Effect of Family-to-Work Enrichment. Journal of Entrepreneurship, $26 \quad$ (2), United States. (Pp.196-219). https://doi.org/10.1177/0971355717716762

OECD. (2018). Entrepreneurship at a Glance 2018 Highlights. In Entrepreneurship at a Glance.

Observatorio Geográfico de América Latina. Extraído de http://www.oecdilibrary.org/industry-and-services/entrepreneurship-at-a-glance-2010/measuringgreen-entrepreneurship 9789264097711-4-en

Ogbor, John O. (2000). Mythicizing and Reification in Entrepreneurial Discourse: IdeologyCritique of Entrepreneurial Studies. Journal of Management Studies, 37 (5), United States. (Pp.605-635). https://doi.org/10.1111/1467-6486.00196

Pato, Maria Lucia; Teixeira, Aurora Amélia C. (2014). Twenty Years of Rural Entrepreneurship: A Bibliometric Survey. Sociologia Ruralis, 56 (1), United States. (Pp. 3-28). https://doi.org/10.1111/soru.12058

Raghuvanshi, Juhi; Agrawal, Rajat; Ghosh, P. K. (2017). Analysis of Barriers to Women Entrepreneurship: The DEMATEL Approach. Journal of Entrepreneurship, 26 (2), India. (Pp.220-238). https://doi.org/10.1177/0971355717708848

Rodrigues Antunes, Luiz Guilherme; Aparecida de Abreu, Arlete; Mendoca Rodrigues, Mayra (2020). True heroines: unveiling the female management of startups' entrepreneurs.

Revista de Gestão e Secretariado, 11 (2), Brasil. (Pp.211-234). https://doi.org/10.7769/gesec.v11i2.1039

Santamaría Escobar, Álvaro Enrique; Moreno Arias, Eider Manuel; Torres Torres, Eliany Fabiola; Cadrazco Parra, Wilson. (2013). La Influencia de la Familia en el Emprendimiento Empresarial: El caso de tres PYMES de los sectores comercial y de servicios en la 
Ciudad de Sincelejo, Sucre. Revista Pensamiento Gerencial, 31 (1), Colombia. (Pp.95-106). https://revistas.unisucre.edu.co/index.php/rpg/article/view/86

Servantie, Vinciane; Cabrol, Matthieu; Guieu Gilles; Boissin, Jean-Pierre (2016). Is International entrepreneurship a field? A bibliometric analysis of the literature (1989-2015). Journal of International Entrepreneurship, 14 (2), United States. (Pp.168-212). https://doi.org/10.1007/s10843-015-0162-8

Shettar, Rajeshwari M. (2020). Women empowerment and women entrepreneurship: an overview. Journal of Xi'an University of Architecture \& Technology, XII (II), China. (Pp.3843-3848). http://xajzkjdx.cn/gallery/338-mar2020.pdf

Singh, Ranjana; Sebastian, Tania. (2018). Familial legacies: a study on Gujarati women and family entrepreneurship. Journal of Global Entrepreneurship Research, 8 (5). United States. https://doi.org/10.1186/s40497-018-0090-x

United Nations. (2020). United Nations Sustainable Development - 17 Goals to Transform Our World. United Nations. United States. Extraído de https://www.un.org/sustainabledevelopment/

Vaca-Trigo, lliana. (2019). Oportunidades y desafíos para la autonomía de las mujeres en el futuro escenario del trabajo. Serie Asuntos de Género. Series de la CEPAL. Comisión Económica para América Latina y el Caribe (CEPAL), Naciones Unidas. Chile. $\quad$ https://www.cepal.org/es/publicaciones/44408-oportunidades-desafios-laautonomia-mujeres-futuro-escenario-trabajo

Velt, Hannes; Torkkeli, Lasse; Laine, Igor (2020). Entrepreneurial Ecosystem Research. Journal of Business Ecosystems, 1 (2), United States. (Pp.43-83). DOI: https://doi.org/10.4018/jbe.20200701.oa1

Véras, Erika Zoeller. (2015). Female Entrepreneurship: from Women's Empowerment to Shared Value Creation. International Journal of Management Science and Business Administration, 1 (3), China. (Pp.50-63). https://doi.org/10.18775/ijmsba.1849-5664$\underline{5419.2014 .13 .1004}$ 